\title{
When is a Stranger a Constructive Trustee? A Critique of Recent Decisions
}

\author{
SUSAN BARKEHALL THOMAS
}

This article explores the conceptual development of third party liability for participation in a breach of fiduciary duty. The author provides a critical analysis of the foundations of third party liability in Canada and chronicles the evolution of context-specific liability tests. In particular, the tests for the liability of banks and directors are developed in their specific contexts. The author then provides a reasoned critique of the Supreme Court of Canada's recent trend towards context-independent tests. The author concludes by arguing that the current approach is inadequate and results in an incoherent framework for the law of third party liability in Canada.
Cet article explore le développement conceptuel de responsabilité civile dans la participation à l'inexécution d'une obligation fiduciaire. L'auteur fournit une analyse critique des fondations de la responsabilité civile au Canada el décrit l'évolution d'essais de responsabilités particulières à une situation. Les essais de responsabilite des banques et des administrateurs sont particulièrement développés dans leur contexte précis. L'auteur fournit ensulte une critigue raisonnée de la récente tendance de la Cour suprême du Canada pour les essais indépendants et particuliers à une situation. L'auteur conclut en prétendant que la démarche actuelle est inadéquate et entraine un cadre incohérent pour la loi sur la responsabilité civile au Canada.

\section{TABLE OF CONTENTS}

I. INTRODUCTION .................... 453

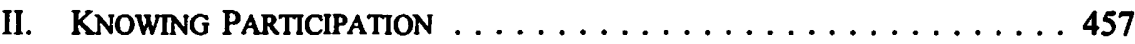

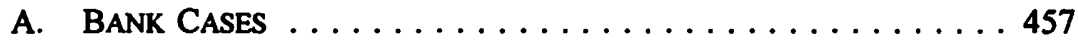

B. APPLICATION OF THE "PUT ON INQUIRY" TEST . . . . . . 459

C. CONCEPTUAL PROBlems WITH THE

"PUT ON INQUIRY" TEST . . . . . . . . . . . . . 463

D. CONCLUSIONS FROM PART II $\ldots \ldots \ldots \ldots \ldots \ldots \ldots 467$

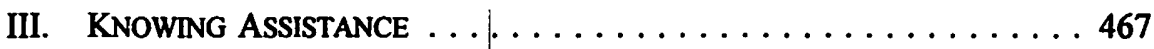

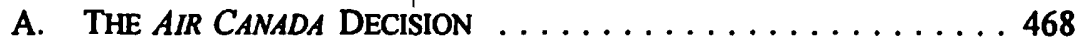

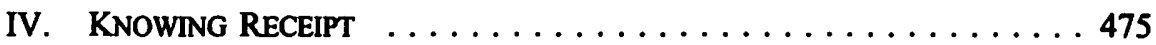

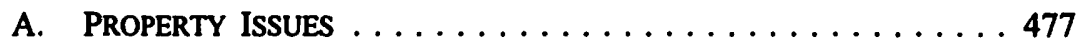

B. UNJUST ENRICHMENT $\ldots \ldots \ldots \ldots \ldots \ldots \ldots \ldots \ldots 478$

C. "NOTICE" AND "DUTY TO INQUIRE" $\ldots \ldots \ldots \ldots \ldots \ldots \ldots 48$

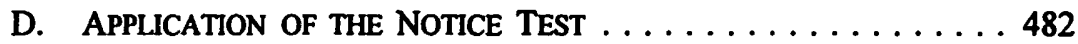

E. HAS THE DEFENDANT "RECEIVED" TRUST PROPERTY? . . . . 486

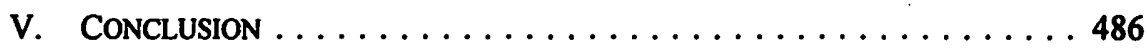

\section{INTRODUCTION}

Fiduciaries often occupy positions of great responsibility. Frequently this responsibility gives the fiduciary control, if not legal ownership, of money or property. However, the fiduciary is obliged, in accordance with equitable principles, to act with the utmost loyalty to the person to whom the fiduciary duty is owed. Unfortunately, not all fiduciaries are worthy of the responsibility given to them, and they misapply the assets in their control. 
When they do so the victim of the fiduciary's wrongdoing will, of course, want to obtain a remedy against the defaulting fiduciary. This may not be possible. The fiduciary may have no money. Or the fiduciary may have disappeared. The victim will then seek another party who can be held responsible for the victim's loss.'

In the 1874 English decision of Barnes v. Addy, ${ }^{2}$ Lord Selborne formulated a rule that while strangers can be liable as constructive trustees, an agent of a trustee is not to be made a constructive trustee merely by acting as agent unless the agent: (1) receives and becomes chargeable with some part of the trust property; or (2) assists with knowledge in a dishonest and fraudulent design on the part of the trustee. ${ }^{3}$

In other jurisdictions Lord Selborne's dictum has long been interpreted as containing two separate limbs, or rules, for the liability of strangers to a trust. ${ }^{4}$ The first limb is "knowing receipt": the category of constructive trusteeship that is applicable where the defendant receives and becomes chargeable with trust property. No liability can arise under this limb of the test unless the defendant can be said to have received property for his or her own benefit. The first limb is also said to encompass "knowing dealing" with trust property that has been received where the stranger did not know of the breach of trust, but the breach becomes apparent before the stranger parts with the property.

The second limb is "knowing assistance": the category of constructive trusteeship applicable because the defendant knowingly assisted the trustee in a dishonest and fraudulent design. This category of constructive trusteeship is not based upon the receipt by the defendant of any trust property, but rather it is said to be based on participation in the trustee's fraud.

The cause of action under Barnes v. Addy is equitable. It is predicated on the notion that the plaintiff is entitled to sue in equity because fiduciary duties were owed to her. Further, the liability of the defendant flows from the wrongdoing of the fiduciary. The defendant is described as "a constructive trustee," but liability is personal only. The defendant can be made to account for the loss of the plaintiff as if he or she were also a fiduciary.

The Barnes v. Addy action must be distinguished from the rules that apply when a plaintiff seeks to trace her property into the hands of a defendant. A plaintiff may attempt

As is recognized in the following quote from Lord Nicholls of Birkenhead in Royal Brunei Airlines Sdn. Bhd. v. Tan, [1995] 2 A.C. 378 (P.C.) at 381-82 [hereinafter Royal Brunei]: "Increasingly plaintiffs have recourse to equity for an effective remedy when the person in default, typically a company, is insolvent. Plaintiffs seek to obtain relief from others who were involved in the transaction, such as directors of the company, or its bankers, or its legal or other advisers. They seek to fasten fiduciary obligations directly onto the company's officers, agents, or advisers, or to have them held personally liable for assisting the company in breaches of trust or fiduciary obligations." (1874), L.R. 9 Ch. App. 244.

Ibid. at 251-52.

For example, in England see Royal Brunei, supra note 1; in Australia see Consul Development Pty. Lid. v. D.P.C. Estates Pty. Ltd. (1975), 132 C.L.R. 373 (H.C. Aus.); in New Zealand see Westpac Banking Corporation v. Savin, [1985] 2 N.Z.L.R. 41 (N.Z. C.A.) [hereinafter Westpac v. Savin]. 
to trace (and therefore identify) her property so that she can assert a continuing equitable title to that property. The equitable personal claim is distinct. The defendant can be liable under Barnes v. Addy even where she never received property from the defaulting fiduciary. Further, the defendant can be liable where property was received but has since been dissipated and can no longer be traced. In both of these cases the plaintiff does not seek to trace assets in order to assert a continuing proprietary interest. The equitable personal claim is therefore more extensive than the tracing/proprietary basis. The plaintiff's remedy is a monetary award.

In the Canadian courts the Barnes v. Addy conceptual division was only recently recognized. In 1993 in the decision of Air Canada v. $M \& L$ Travel Ltd. ${ }^{5}$ the Supreme Court of Canada adopted the two limbs of liability from Barnes v. Addy. The Court made it clear that liability for assisting in a breach of fiduciary duty and liability for receiving trust property were two conceptually independent ways in which a stranger could participate in a breach of duty. The Court then formulated a liability test for "knowing assistance" that is faithful to the literal words of Lord Selborne. It was held that actual knowledge of the breach was required" and that the breach had to be "dishonest and fraudulent."

In late 1997 the Supreme Court handed down the decisions of Gold v. Rosenberg ${ }^{7}$ and Citadel General Assurance Company v. Lloyds Bank Canada. ${ }^{8}$ These decisions confirm that the two limbs of Barnes v. Addy are discrete tests of liability. Both cases dealt with "receipt," and the Court used the opportunity to state the relevant principles. The Court said that the liability of the recipient is based in restitution because the defendant will be unjustly enriched if not required to return the value of the property received. However, liability is not strict, and the plaintiff must prove "notice" on the part of the defendant before there is any restitutionary obligation. The Court relied heavily on English authority and English commentaries.

The distinction between the "knowing receipt" category and the "knowing assistance" category is not just semantic. It is particularly relevant to an agent of a trustee; for example, take the position of a solicitor. Trust money may pass through the hands of the solicitor, but the solicitor only deals with the property as a channel and receives no personal benefit from handling the property. This defendant is not a recipient for the purposes of the first limb of Barnes v. Addy. Thus the plaintiff would have to satisfy the criteria for the "knowing assistance" limb of liability.

The distinction is also important to banks. A bank may either act as agent or on its own behalf. Where the bank sets-off a debt in one account against a credit in another account it is not acting as agent, and it receives money on its own account. ${ }^{9}$ However, when paying in cheques, the bank is acting as agent and retains no actual benefit, although it

(1993), 108 D.L.R. (4th) 592 [hereinafter Air Canada]. Although recklessness and wilful blindness would suffice.

(1997), 152 D.L.R. (4th) 385 [hereinafter Gold].

(1997), 152 D.L.R. (4th) 411 [hereinafter Citadel Assurance].

See, e.g., Westpac v. Savin, supra note 4. 
receives the money on the client's behalf. The bank which pays in a cheque has not received money under the first limb of Barnes $\mathrm{v}$. Addy. However, the bank that sets-off one account against another has received property and is within the scope of the first limb.

In adopting the Barnes v. Addy tests the Supreme Court has adopted a new conceptual framework for third party liability in Canada. Prior to these three Supreme Court decisions, Barnes v. Addy was virtually ignored. The Canadian courts had developed a number of other tests to determine the liability of a third party. These tests were highly context dependent, and consequently, the identity of the defendant was crucial to the formulation of liability. Thus the liability test applicable to banks was significantly different from the test applied to company directors. For banks the question was whether the bank had knowingly participated in the breach of duty. The defendant would be liable if it was "put on inquiry." In applying this test the courts protected banking practice. Where company directors were defendants, a version of "knowing assistance" was applied. No distinct category of receipt liability was recognized.

By using context-specific tests, the Canadian courts were sensitive to the situations in which third party liability arose. The different tests allowed for a consideration of risk allocation in decision making. In other words, the courts made some attempt to determine which party was in the best position to take steps to prevent the fraud.

The aim of this article is to demonstrate that the adoption of the Barnes v. Addy distinctions is a retrograde step. Unfortunately, the effect of the Supreme Court decisions is to abandon context-dependent tests in favour of more generic criteria of liability. According to the Supreme Court, what matters is whether the defendant received or assisted, not who the defendant is. In the author's opinion, these context-neutral categories do not establish the appropriate incentives for defendants to prevent fiduciary fraud. A more suitable liability framework would take into account the identity of the defendant and the role played by that defendant in the transaction with the fiduciary.

In Part II the case law on "knowing participation" will be summarized and explained. This part demonstrates how the Canadian courts were applying an intuitive economic analysis in framing liability tests. Although more work was required to develop a coherent set of principles, the approach of the courts demonstrated that flexibility was required in the framing of any liability test. Part III addresses "knowing assistance" liability prior to Air Canada and explains the effect of the Air Canada decision. This part highlights some of the implications and potential problems of the decision. In particular, the defects of a generic test for knowing assistance will be identified. Part IV addresses receipt liability, offering a critique of the recent Supreme Court decisions of Citadel Assurance and Gold. Particular attention will be paid to the decision of Gold and the Supreme Court's application of the legal tests to the facts. It will be demonstrated that in Gold the majority's reasoning regarding whether the defendant knowingly received trust property is flawed. 


\section{KNowing PaRticipation}

Banks in Canada have been the most common defendant in third party liability actions. ${ }^{10}$ Until 1997 when assessing the liability of banks, the Courts drew on their own lines of authority rather than closely following the Barnes v. Addy tests of liability.

The liability rule adopted was one of "knowing participation." Although it will be shown that this test was not completely successful, it did have some important features. Most importantly, it is significant that the courts interpreted knowledge in light of the commercial context in which the case appeared. Thus the level of knowledge required for liability was affected by the identity of the defendant. This is evident because the knowing participation test was applied more leniently against banks than against other types of defendants.

Judges intuitively decided how the risk of loss from fraud should be best allocated between the defendant and the plaintiff, bearing in mind the identity of the defendant. The leniency toward banks demonstrates a conclusion by the Canadian courts that this class of defendant should not bear significant responsibility for fiduciary fraud. However, no explicit consideration was given to issues of risk allocation. Accordingly, the decisions suffered from a lack of direction and clear policy rationale.

The liability rule will be considered in its application first to banks and, second, to nonbank defendants.

\section{A. Bank Cases}

The test of "knowing participation" derives from the judgment of Schroeder J.A. for the Ontario Court of Appeal in Fonthill Lumber Ltd. v. Bank of Montreal. ${ }^{12}$ The level of knowledge which he held sufficient to render a bank liable included whether the bank knew of "circumstances which should put it on inquiry."'3 What does this mean?

"Third party liability" is a convenient shorthand term to refer to equitable personal liability for participation in a fiduciary's fraud.

However, there are a couple of decisions which incorrectly apply the knowing assistance limb from Barnes v. Addy in conjunction with the Canadian line of authorities. The decisions effectively equate knowing assistance and knowing participation, and the distinction between assistance and receipt is not perceived. The cases are cited in footnote 56 below.

(1959), 19 D.L.R. (2d) 618 (Ont. C.A.). The other judges were Porter C.J.O. and McGillivray J.A. [hereinafter Fonthill].

13 Ibid. at 633. On the facts, the bank accepted a deposit of trust funds to its customer's account and used the trust funds to reduce the customer's overdraft liability. Schroeder J.A. held that the bank manager knew that the monies that went into the customer's account were for construction, he was presumed to know that under legislation such funds were impressed with a trust in favour of contractors, and the manager "must also be taken to have known that at the material time the customer was financially embarrassed" and not in a position to pay those creditors. Nevertheless, the manager pressed for payment of the overdraft. Clearly, the knowledge of the bank manager goes beyond merely being "put on inquiry." 
Canadian courts had not developed any jurisprudence on the types of knowledge that a defendant could have, nor had it been determined which types of knowledge should suffice for liability. However, in England (and subsequently other jurisdictions) attempts had been made to classify types of knowledge for the purposes of third party liability. The most enduring of these categorizations was formulated by Peter Gibson J. in Baden, Delvaux and Lecuit v. Société Generale pour Favoriser le Développement du Commerce et de l'Industrie en France $S A .{ }^{14}$ In that case, knowledge was broken into five separate mental states as follows: (1) actual knowledge; (2) wilfully shutting one's eyes to the obvious; (3) wilfully and recklessly failing to make such inquiries as an honest and reasonable person would make; (4) knowledge of circumstances that would indicate the facts to an honest and reasonable person; and (5) knowledge of circumstances that would put an honest and reasonable person on inquiry.

Categories (1), (2), and (3) were said to encompass forms of actual knowledge, while categories (4) and (5) encompassed constructive knowledge. ${ }^{15}$ To a reader familiar with the Baden categories, the statement by Schroeder J.A. suggested knowledge type (5): "knowledge of facts which would put an honest and reasonable man on inquiry."

But this may not be what Schroeder J.A. meant. In Banque Romande v. Mercantile Bank of Canada ${ }^{16}$ Schroeder J.A. again considered a bank's liability for the breach of trust of its customer. As in Fonthill, Schroeder J.A. was giving the decision of the Ontario Court of Appeal. ${ }^{17} \mathrm{He}$ relied on his own judgment in Fonthill as a correct statement of the applicable law. ${ }^{18}$ In holding the defendant bank not liable, Schroeder J.A. stated that the plaintiff had been unable to bring home knowledge to the defendant, and nothing in the evidence suggested "that they were put on enquiry but closed their eyes to something which should have been obvious to them."19

Stated in this context, the reference to "put upon enquiry" suggests a higher standard of Baden knowledge than the test in Fonthill. The formulation in Banque Romande suggests wilful blindness (type 2) or a wilful or reckless failure to make the inquiries that a reasonable person would have made (type 3 ).

The pivotal case for banks was the Supreme Court decision of Carl B. Potter Ltd. v. Mercantile Bank of Canada. ${ }^{20}$ This was a case where a company (Anil) sought tenders, requiring tenderers to provide a cheque as a guarantee of performance. Anil undertook to deposit the cheques in a trust account, but it did not do so. Ultimately, the proceeds of

[1983] B.C.L.C. 325 (Ch.D.) [hereinafter Baden].

Categories (4) and (5) are sometimes said to be examples of constructive knowledge, while other times they are said to represent constructive notice. For a thorough discussion on the overlapping use of "knowledge" and "notice" in the context of knowing assistance and knowing receipt see $S$. Gardner, "Knowing Assistance and Knowing Receipt: Taking Stock" (1996), 112 L.Q. Rev. 56. (1971), 20 D.L.R. 633 (Ont. C.A.) [hereinafter Banque Romande].

The other judges on the bench were Brooke and Amup JJ.A.

Fonthill was also followed in Groves-Raffin Construction Ltd. v. Bank of Nova Scotia (1975), 64 D.L.R. (3d) 78 (B.C. C.A.) [hereinafter Groves-Raffin].

Supra note 16 at 645.

(1980), 112 D.L.R. (3d) 88 (S.C.C.) [hereinafter Carl B. Potter]. 
one tenderer's cheque were used to reduce Anil's liability to its bank. The tenderer sued the bank for the return of the funds.

In giving judgment for the Court, ${ }^{21}$ Ritchie J. cited Halsbury's Laws of England for the proposition that "a banker may be a constructive trustee of money in his customer's account and in breach of that trust if he pays the money away, even on the customer's mandate, in circumstances which put him on inquiry."22 Ritchie J. held the bank liable on the basis that the "[b]ank was in possession of sufficient information which required its vice-president and assistant manager to take steps to ascertain the character of the funds which were being deposited."23

A significant aspect of the decision was that the bank was liable even though it did not actually know the funds were trust funds. The fact that it was put on inquiry as to the possible trust character of the funds, and did not then inquire, was sufficient to render it liable as constructive trustee. Actual knowledge of the customer's breach of trust was not required. The bank was liable if it knew that the funds might be subject to a trust.

\section{B. APPLICATION OF THE "PUT ON INQUIRY" Test}

The application of the "put on inquiry" test from Carl B. Potter has not been straightforward. The term has been given a broad range of meanings.

It has been said that

[t]he principle is so well established ... it is difficult to discern any distinctive pattern of application ... it cannot be said that substantive doctrinal formulation of the principle has been achieved.... Certain aspects of the application of these principles remains uncertain ... it remains unclear in what factual circumstances a bank will owe a duty of inquiry to any person claiming an interest in funds within the control of the bank ... it is unclear as to what particular facts will place a bank on inquiry. ${ }^{24}$

The other judges on the bench were Laskin C.J.C., Dickson, Beetz, Etsey, McIntyre, and Choinard JJ.

Carl B. Potter, supra note 20 at 90, Ritchie J. citing Halsbury's Laws of England, vol. 3, 4th ed. (London: Butterworths, 1980) at 48, para. 60. The Halsbury reference is footnoted to the English cases of Selangor United Rubber Estates Lid. v. Craddock (No. 3), [1968] I W.L.R. 1555 [hereinafter Selangor]; and Karak Rubber Co. v. Burden (No. 2), [1972] 1 W.L.R. 602. Thus in discussing the "put on inquiry" test, Canadian judges sometimes refer to these English cases to support or explain the test. Carl B. Potter, ibid. at 91.

24 M.H. Ogilvie, Canadian Banking Law (Canada: Carswell, 1991) at 454-56. At 455, n. 72 Ogilvie cites an extensive list of cases which have applied the test. An attempt has been made by Professor Ellinger to outline a structure for the circumstances in which various levels of knowledge should apply: E.P. Ellinger, "Reflections on Recent Developments Concerning the Relationship of Banker and Customer" (17th Annual Workshop on Commercial and Consumer Law, Faculty of Law, University of Toronto, 16-17 October 1987) (1988) 14 Can. Bus. L.J. 129 [hereinafter "Reflections"]. Professor Ellinger suggests, at 164, that the level of knowledge required by the bank could be determined by the relationship (if any) existing between the banker and the plaintiff beneficiary. He suggests that where the beneficiary is itself a customer of the bank or if the bank is specifically aware of the rights of the beneficiary, then the bank should be liable if it has any of the Baden levels of knowledge. In other scenarios, the bank should not be liable unless it has knowledge types (1), (2) 
The formulation from Carl B. Potter theoretically rendered a bank liable on the basis of mere constructive knowledge that a trust existed and did not require any knowledge of a breach. This test could be expected to cause grave concern amongst bankers. However, despite this apparently low threshold, the courts frequently applied the "knowing participation" test in a manner that was very favourable to the defendant banks. As a result, liability was rarely imposed unless there was a high degree of knowledge.

From a risk avoidance perspective, the implicit policy objective in these cases is that a bank should not lightly be made to bear the cost of fiduciary fraud. The courts said that a reasonable banker was not put on inquiry unless there were very clear facts indicating that the bank may be dealing with trust funds. In many cases, the "put on inquiry" test was implicitly, if not explicitly, equated to "wilful blindness."25

Further, the decisions and the commentary above demonstrate that the concept of "put on inquiry" is still in flux because it is consciously applied with reference to context. This leads to flexibility, and it allows judges to determine intuitively when the risk of fiduciary fraud should be borne by the bank. This requires judges to assess the ability of the defendant to prevent fraud and the costs that will be incurred by the defendant if it is required to implement preventative mechanisms. But this analysis is not made explicit.

The facts and findings from two cases illustrate the point. In Perlmutter Shore Ltd. v. Bank of Montrea ${ }^{26}$ the bank's customer was in the construction industry. It was obliged to hold funds received for subcontractors on a statutory trust. The bank knew that its customer intended to subcontract nearly all of its work. Thus the bank knew that a significant proportion of all of the company's receivables would be subject to statutory trust obligations in favour of third parties.

Over a period of two years the company's financial position was strained, and it depended on the timely payment of receivables. The bank knew that several large

or (3) from Baden. This is an attempt to formulate specific guidelines based on the context of the transaction. These are the type of guidelines that should have been formulated in the courts.

In Ansell v. LaPrairie (1989), 32 E.T.R. 85 at 101, Moshansky J. cited Carl B. Potter and a later case, Grinnell Fire Protection Systems Co. v. Bank of Montreal (1985), 21 C.L.R. 44 [hereinafter Grinnell, where, in his view, a bank was held to be liable because "the circumstances clamoured for inquiry but the Bank preferred to remain wilfully blind." In the opinion of Moshansky J. this was also such a case. In fact, in Grinnell Gow L.J. did not apply the "put on inquiry" test; instead, he relied on the Barnes v. Addy limb of knowing assistance. Note, however, that the bank had actually received funds, not just assisted. Regarding the "put on inquiry" test, see also Overhead Door Co. of Regina (1973) v. Saskatchewan Economic Development Corp., [1985] 2 W.W.R. 458 (Sask. Q.B.), affd [1988] 2 W.W.R. 572 (Sask. C.A.). Estey J. applied Perlmutter, Fonthill, and Carl B. Potter and held that the defendant bank was put on inquiry. Estey $\mathrm{J}$. did not refer to the term wilful blindness, but the facts were strong. He said that the bank was put on inquiry because (1) it received a cheque for deposit to its customer's account which it knew was a final advance on a construction project; (2) the payer had inquired about the contractor's financial position; (3) the bank had discussed the payment with the customer, and the customer did not suggest that beneficiaries had been paid. See also Heating Engineering Installations (1981) Lid. v. Raymond Contractors Lid. (1986), 24 C.L.R. 264 (Sask. Q.B.). 
receivables were unlikely to be paid. When the customer deposited $\$ 50,000$ into its current account, the bank appropriated that amount to the customer's loan account.

The bank had actual knowledge of the customer's business and of the customer's financial state, which would have made it simple for any bank officer to identify that the customer was not beneficially entitled to funds received. Despite this knowledge, the bank appropriated the funds to ensure that its debt was minimized. Clearly, there was not enough money to go around, and the bank's actions were prejudicial to unpaid subcontractors.

Justice Eberle held the bank liable because it "had knowledge of a sufficient range of facts and circumstances to oblige it to make some inquiry before appropriating to itself the only funds in [the] account." employees simply pulled the bank's security blanket down over their eyes." ${ }^{28}$

The second case is Toronto-Dominion Bank v. General Glass \& Aluminium Co. ${ }^{29}$ The bank's customer was in the construction industry and was obliged to hold funds on statutory trusts in favour of subcontractors. The bank and the customer had a long term relationship, and bank staff had visited the customer's premises. The bank was unhappy with the client's overdraft level, and it had been considering extraordinary methods of reducing the debt. It was keen to terminate the relationship with the customer. The client came to the bank wanting to urgently deposit a cheque toward his company's debts and to obtain a release of the securities held by the bank. The cheque in fact comprised trust funds, although the particular bank employee did not appreciate this.

It was held that the bank had been put on inquiry because it was "not reasonable for the Bank to hide behind and rely solely on the honest though mistaken belief of an inexperienced employee." ${ }^{30}$

These decisions seem to reflect an intuitive risk allocation analysis. In both of these cases it seems that the nature of the transaction and the close relationship between the bank and the customer put the bank in a position where it could easily have prevented the fraud. The bank was in possession of the necessary information, and it would not have been costly to make inquiries to satisfy itself that third party interests were not being compromised. It is, therefore, appropriate to expect the bank to make inquiries to protect third parties. The fact that it did not do so led to its liability.

This reasoning remains unstated. As a consequence, any assumptions made by the judges in relation to the bank's ability to prevent fraud are not easily identified and cannot be tested. Further, decisions become tied to their specific facts and offer little guidance for future development of principle.

Ibid. at 583.

Ibid.

(1992), 5 C.L.R. (2d) 31; [1992] O.J. No. 2504 (Gen. Div.), online: QL (OJRE) thereinafter General Glass cited to QL].

30

Ibid. at para. 33. 
Two later cases using the "put on inquiry" test reinforced its context-specific nature. Unfortunately, however, they did not assist in clarifying the underlying risk allocation principles. In Arthur Andersen Inc v. Toronto-Dominion Bank ${ }^{31}$ two members of the Court of Appeal for Ontario ${ }^{32}$ stated:

The real question is: at what stage in its dealings with a customer with trust funds on deposit does a bank's knowledge of its customer's affairs impose a duty to inquire as to the possible misapplication of trust funds? ? $^{33}$

The judges answered their own question as follows:

We consider that the law on this point can be summarized thus: in the absence of sufficient facts or circumstances indicating that there is a good possibility of trust beneficiaries being unpaid there is no duty of inquiry on a bank to determine whether the trades have been paid or will be able to be paid."

The judges also made it clear that the level of inquiry expected of the bank once a duty had arisen will be shaped by the prior relationship between the bank and its customer. ${ }^{35}$ Regarding wilful blindness, the judges said that "wilful blindness can only be of relevance from the time when a duty to inquire arises." ${ }^{.36}$

It is difficult to know exactly what standard is being offered. Clearly, the bank's relationship with its customer and the type of transaction involved will affect the bank's position. But if there must be a "good possibility" of a breach, does this mean that an honest and reasonable person would have made inquiries? Or is a higher level of knowledge involved? The standard is not completely objective, as the level of inquiry to be made depends on the actual relationship between the bank and its customer. Is any failure to inquire fatal, or must there be a wilful or reckless failure to inquire? ${ }^{37}$ Further, how is the concept of "wilful blindness" to be incorporated into this test?

(1994), 17 O.R. (3d) 363 (C.A.) [hereinafter Arthur Andersen].

Grange and McKinlay JJ.A., jointly giving the majority judgment, found the defendant bank liable. The minority judge was Abella J.A.

Supra note 31 at 380 . The trust in question in Arthur Andersen was a statutory trust, imposed for the benefit of suppliers and contractors within the construction industry. The bank operated accounts for a group of companies involved in housing construction, and the companies paid funds subject to the statutory trust into their operating accounts. The bank had implemented an accounting system for the group that required the overall balance of the accounts to be in credit, although individual accounts could be in overdraft. Eventually the companies were unable to keep the system in credit, and the bank seized all of the funds in the accounts.

Ibid. at 381 [emphasis added].

lbid. at 383.

Ibid. at 384 .

Professor Margaret Ogilvie has suggested that the case adopts knowledge "around levels (iv) or (v)." M.H. Ogilvie, Case Comment on Arthur Anderson Inc. v. Toronto-Dominion Bank (1994) 73 Can. Bar Rev. 592 at 611 . At 614 she states that she regards the decision as arresting "the accelerating trend to higher and higher duties for banks, impossible to perform." 
This decision clearly demonstrates the context-specific nature of the "knowing participation" test. What it does not offer is a set of explicit guidelines for other courts to follow.

The Arthur Andersen decision was applied by the Manitoba Court of Appeal in $R e$ Glenko Enterprises Ltd. and Bank of Montreal. ${ }^{38}$ On the facts of the case before him, Scott C.J.M. found that the bank was not liable as a constructive trustee. He held that the bank did not wilfully or carelessly ignore the facts. After exonerating the bank he stated:

Nothing I have said in these reasons should be interpreted as absolving banks which operate single accounts for general contractors of all responsibility for breaches of trust committed by such customers to the detriment of subcontractors or suppliers. If a bank is wilfully blind or manifestly negligent or if it intentionally prefers itself at the expense of such creditors, then it will share liability for these breaches of the trusts. ${ }^{39}$

Is a bank "manifestly negligent" when it fails to make the inquiries that an honest and reasonable person would have made? Is there a distinction between negligent and manifestly negligent? Further, is this test to be relevant in other scenarios?

\section{Conceptual Problems with the "Put on Inquiry" Test}

The courts never resolved whether liability required notice of the breach of duty or mere notice that a trust might be in existence. In Fonthil ${ }^{40}$ and Banque Romande ${ }^{41}$ the Court asked whether the bank had notice of the customer's breach of trust. In these cases there was a real attempt to determine whether the bank had participated in the breach. In the Carl B. Potter case the question was whether the bank had notice that the funds were trust funds. Most recently, in the Arthur Andersen decision, the Ontario Court of Appeal reverted to the question of whether the bank had notice of the customer's breach of duty.

It is suggested that this confusion is attributable to the use of a generic "knowing participation" test. The cases considered above actually form two distinct groups. The position of a bank defendant in a case such as Banque Romande is not the same as the position of the bank in Carl B. Potter, and their liability should not be governed by the same test. The Carl B. Potter case is not a true case of knowing participation.

Consider the position of a bank that appropriates funds in a deposit account to reduce a customer's liability on its overdraft. If the bank has notice that the funds are trust funds, the bank knows that its action of appropriation is prejudicial to the rights of the beneficiaries: it has no right to use those funds to reduce the customer's debt. The bank's own conduct is wrongful toward the beneficiaries, irrespective of whether the fiduciary 
has committed a breach of duty. ${ }^{42}$ By appropriating the funds the bank has committed a wrong against the beneficiaries that is independently actionable by the beneficiaries. The bank's liability is not contingent upon a determination that the customer breached its fiduciary duty to the beneficiary.

Carl B. Potter and the other appropriation cases fall into this category. In Carl B. Potter the customer was not acting in breach of trust. The customer deposited the funds with the bank, instructing the bank that the funds were to be kept separate from the customer's own funds because they were tender cheques. This initially occurred. However, the bank's later dealings with the funds, without its customer's knowledge or instruction, led to the funds being merged with the customer's funds and then being used by the bank to reduce the customer's debt to the bank. Carl B. Potter is, therefore, not authority for knowing participation in its strict sense. Instead, the bank itself was the primary wrongdoer.

Authorities that are true knowing participation are Fonthill and Banque Romande. In Fonthill the customer presented cheques for deposit into the customer's overdrawn account. The funds were subject to trust obligations. It is a breach of duty for the customer to use trust funds for its own purposes. The bank knew that the funds were subject to a trust and could not be used by the customer for its own benefit. Nonetheless, the bank accepted the cheques in payment of the customer's debt. By accepting the cheques for deposit and as payment of the customer's debt, the bank received the trust funds, knowing that the transfer was inappropriate.

In Banque Romande the bank followed the customer's payment instructions regarding funds. One instruction was for the bank to use funds to reduce the customer's debt. The bank was not liable because it did not know that the funds were subject to fiduciary obligations and that they were being misused by the fiduciary.

This conceptual confusion illustrates that the courts failed to sufficiently develop the "knowing participation" test to take account of different types of bank misappropriation. Differences in the factual scenarios were not perceived, and no coherent tests were developed to take account of the factual variations.

However, despite these criticisms, it can be seen that the courts genuinely attempted to frame the liability rules in context. The courts were conscious of the commercial role played by banks and attempted to protect their commercial position. However, in circumstances where the bank had a high level of knowledge, liability was imposed. This seems to reflect the view of the courts that in these circumstances the bank could have prevented the fraud at low cost and should bear responsibility for its failure to take steps. 


\section{NO BENEFIT RECEIVED BY BANK}

There are very few cases in which a bank defendant did not receive trust funds in its transaction with the fiduciary. However, in the cases where the bank's participation did not involve obtaining a benefit, the "knowing participation" test was applied differently. In CIBC Mortgage Corp. v. Lloyds Bank Canada ${ }^{43}$ the defendant bank participated in a breach of trust by permitting a solicitor to deposit trust funds into his personal account and to then disburse them. ${ }^{44}$ Austin J. held the defendant not liable and noted "[i]t is of some significance that in Reckitt and Potter, as in many of the cases where the banks were held accountable, the defendant banks were the ultimate beneficiaries."

Obviously, the nature of the defendant's participation affected its liability. Austin J. was clearly concerned to ensure that he did not impose unrealistic standards on banks. However, it appears that for Austin J., at least, the "knowing participation" and "put on inquiry" tests gave him insufficient guidance on this point. ${ }^{46}$ What was really required here was a closer analysis of the type of transaction and whether the bank was in a position to prevent the fraud. Just because it did not benefit from the transaction does not of itself mean that the bank should avoid responsibility if it could have taken steps to prevent the fraud. The customer's history in relation to the account and the amounts involved may have warranted further inquiry by the bank before complying with his instructions.

\section{NON-BANK CASES}

Prior to Gold v. Rosenberg the "knowing participation" test was also applied to determine the liability of non-bank lenders. ${ }^{47}$ In this area it is clear that the courts applied a version of the "put on inquiry" test that was modified to take into account the identity of the defendants. Non-bank defendants were liable with a lower standard of knowledge than was required for banks. This modification of the test was a conscious one.

(1989), 68 O.R. (2d) 310 (H.C.J.).

4 The deposit was for a sum in excess of $\$ 50,000$. The lawyer sought to immediately withdraw half of the deposit.

is Supra note 43 at 319-20. Referring to Midland Bank Lid. v. Reckitt, [1933] A.C. 1 (H.L.).

4 See also Bank of Nova Scotia v. Bank of Montreal (1982), 38 O.R. (2d) 723 (H.C.J.). The bank initially intended to benefit from the transaction, but no benefit ultimately eventuated. Because of the bank's intention to benefit, Justice Craig treated the case as similar to Carl B. Potter, citing the English banking case of Gray v. Johnston (1868), L.R. 3 H.L. I at 11 for the proposition that if the bank "designed or stipulated for" a benefit, this was evidence of complicity. Craig J. applied the objective test, and at (1982), 38 O.R. (2d) 723 at 734 stated that the banker had "knowledge of circumstances that would have put him or any honest, reasonable banker on inquiry whether a breach of trust was being committed." He then added that the bank manager "shut his eyes to the circumstances." See also M.H. Ogilvie, "Banker and Customer Revisited" 65 Can. Bar Rev. 3 at 23. But see Jarvis v. Van-Martin Realty Ltd. (1986), (1987), 25 C.C.L.I. (B.C.S.C. (T.D.)). The test of knowing participation was applied without analysis to determine the liability of a company director. 
In Andrea Schmidt Construction v. Glatt ${ }^{48}$ and G.C. McDonald Supply Limited v. Preston Heights Estates ${ }^{49}$ the position of non-bank lenders was distinguished from that of banks. In Andrea Schmidt Saunders J. noted that in the banking cases "one of the issues to be considered was whether the bank was dealing with its customer in the ordinary course of business rather than participating in a breach of trust." ${ }^{\text {"50 }} \mathrm{He}$ then added, "the relationship of banker and customer is not a factor in the transaction we are considering."

In these two cases the lenders were liable although their level of knowledge did not approach the "wilful blindness" standard. Instead, their liability was determined on the basis that a reasonable person would have made inquiries on the facts known to them. ${ }^{52}$ The facts in Andrea Schmidt are illustrative. This defendant was liable despite an explicit acceptance by both parties in that case that the actions of the mortgagee were consistent with the usual practice in the industry. It was usual practice for a lender on a construction project to search title to identify liens or encumbrances, but it was not usual to inquire "as to the status of trade debts." ${ }^{.53}$ Further, at the time when the defendant accepted funds from the contractor, the plaintiff's claim against the funds had not yet accrued.

The decision appears to have increased the standard required of a non-bank third party defendant because it required the defendant to make more than usual inquiries if the lender was to benefit outright from the transaction. ${ }^{54}$

These cases offer no coherent set of principles explaining why a non-bank lender should be under a different liability regime than a bank. What is it about the nature of banks, as institutions, that entitles them to the protection of a higher level of knowledge before liability will be imposed? No justification is given for the imposition of a different standard on non-bank lenders.

(1979), 104 D.L.R. (3d) 130 (Ont. H.C.J.), aff'd (1980), 28 O.R. (2d) 672 (C.A.) [hereinafter Andrea Schmidt]. The defendant was a mortgagee lending money to a borrower for construction purposes. The money lent was subject to a statutory trust in favour of subcontractors and suppliers. At the request of its customer, the defendant withheld some of the monies to be advanced and applied them to reduce a second loan of the customer.

(1992), 10 O.R. (3d) 409 [hereinafter G.C. McDonald Supphy]. The mortgagee lent money for construction purposes and retained or appropriated some of the advance monies to repay indebtedness of the borrower. The plaintiffs were unpaid subcontractors and suppliers, suing under the statutory trust provisions.

Supra note 48 at 137.

Ibid.

Ibid. at 138; G.C. McDonald Supply, supra note 49 at 428.

Supra note 48 at 137.

But see Di-Mar Construction Lid. v. Wellington Business Centre Inc. (1993), 11 C.L.R. (2d) 68 (Ont. Gen. Div.). This was another case where a financier lent monies for a construction project. The financier was not a bank. Doyle J. cited Andrea Schmidt, but also cited Perlmutter, supra note 26, a banking case. Doyle J. made no distinction between bank and non-bank lender defendants. 


\section{CONClusions From PART II}

Clearly, the "knowing participation" test was flawed. It appears that the test was developed by judges applying an intuitive response to the question of participatory liability. There is a clear theme that banks should not bear a significant burden of liability for fiduciary fraud. But why is this? Is this because the courts instinctively feel that banks are not able to implement risk avoidance mechanisms and still meet the commercial demands placed on them? Does this explain why non-bank lenders are any better able to implement such mechanisms? Further, why is it that receipt of a benefit should change the liability test?

These questions were never sufficiently examined. However, the courts were moving toward the development of multiple context-based liability tests. Ideally, these would have involved explicit consideration of the role played by the defendant in the transaction with the fiduciary and the ability of the defendant to take precautions to prevent the fraud.

In Part III it will be demonstrated that the Barnes v. Addy formulation adopted by the Supreme Court prevents courts from developing context-specific criteria for liability.

\section{KNOWIng Assistance}

Prior to the Supreme Court decision in Air Canada, ${ }^{55}$ there was some recognition of the knowing assistance head of liability as expounded in Barnes v. Addy. The cases which adhered to the Barnes v. Addy formulation were largely developed independently of the banking authorities. ${ }^{56}$

The "knowing assistance" test was most frequently applied to determine the liability of directors of corporate trustees. ${ }^{57}$ In this context the authorities were split on the

Supra note 5.

There are a number of authorities which incorrectly applied the Barnes v. Addy knowing assistance test. In Canadian Imperial Bank of Commerce v. Valley Credit Union Lid. (1989), 63 D.L.R. (4th) 632 (Man. C.A.) [hereinafter Valley Credit Union], Philp J.A., in the majority, applied Barnes v. Addy but clearly had difficulty in distinguishing the difference between receipt and assistance cases. When discussing the knowledge requirement, Philp J.A. considered Carl B. Potter and the subsequent history of Selangor, supra note 22, in Canada and the UK. In doing so he made no attempt to differentiate between assistance and receipt cases. The only suggestion he made that there was some distinction between the cases was when he said in Valley Credit Union, at 642, that the common elements in bank cases are "an unusual transaction, one that is out of the ordinary course of business; and a benefit to the bank. It has long been recognized that a personal benefit is an important factor in imputing knowledge." Similarly, in Bank of Nova Scotia v. First City Trust Co. (1993), 122 N.S.R. (2d) 199 (N.S. S.C. (T.D.)); Anand v. Medjuck, [1995] O.J. No. 2571 (Gen. Div.), online: QL (OJRE); McEachern v. Royal Bank of Canada, [1991] 2 W.W.R. 702 (Alta. Q.B.) the knowing assistance limb of Barnes $v$. Addy is cited and applied. The distinction between knowing assistance and knowing receipt is clearly not understood in these decisions.

Barnes v. Addy was also cited as authority for knowing assistance in a handful of cases that involved neither company directors nor banks. See MacDonald v. Hauer (1976), 72 D.L.R. (3d) 110 (Sask. C.A.) (regarded as the classic statement of the principle); Winslow v. Richter (1989), 61 D.L.R. (4th) 549 (B.C. S.C. (T.D.)); MacMillan Bloedel Lid. v. Binstead (1983), 14 E.T.R. 269 (B.C. S.C. (T.D.)). 
precise formulation of the test. ${ }^{58}$ One stream of authority adhered closely to Lord Selborne's statement of principle. The other line of authority held that it was sufficient for liability if the breach of trust was innocent or negligent. This latter line of authority was particularly interesting considering the protective approach that the courts had adopted towards banks in applying the "knowing participation" test.

In 1993 the Supreme Court decision of Air Canada conclusively settled the formulation of liability for knowing assistance. The consequence of this decision is to reverse the trend toward context-specific liability rules, in favour of a single rule for assistance. Prior to Air Canada the divergence in authority demonstrated that some judges felt that directors of corporate trustees could be required to bear a higher burden of liability. After Air Canada it appears that there will be no scope for such an assessment. All defendants will be governed by the same liability rule, regardless of their ability to prevent the fraud.

\section{A. The AIR CANADA Decision}

This case concerned the liability of Valliant, the director of a travel agency. The travel agency issued tickets for Air Canada, and pursuant to an agreement it was required to hold the proceeds of ticket sales in trust for the airline. This was not done. All monies were put into a single operating account with the agency's bank. The travel agency had a line of credit with the bank. The agency had financial troubles and closed its doors while the directors fought amongst themselves. Valliant attempted to put trust funds aside for the airline, but the account had been frozen and his co-director was giving conflicting instructions to the bank. The bank appropriated the funds in the operating account to extinguish the company's liability under the overdraft. The airline was never paid. Air Canada attempted to make the directors personally liable for the shortfall and was successful. ${ }^{59}$

The Supreme Court of Canada unanimously held that Valliant was personally liable to the airline to repay the amount appropriated by the bank. The main majority judgment was given by Iacobucci $J^{60}$

As a starting point, lacobucci $J$. indicated that "[w]hether personal liability is imposed on a stranger to a trust depends on the basic question of whether the stranger's conscience is sufficiently affected to justify the imposition of personal liability."61 Such a statement could have been used to support a flexible approach to liability. This was not the case.

Iacobucci J. then cited Barnes v. Addy as authority for the two ways in which a third party to a trust can be liable for participation: by knowing receipt and dealing and by

s8 The authorities are reviewed in the judgment of lacobucci J. in Air Canada, supra note 5.

59 We can only wonder why the bank was not sued for "knowing participation." The decision of Canadian Pacific Air Lines Lid. v. Canadian Imperial Bank of Commerce (1987), 42 D.L.R. (4th) 375 (Ont. H.C.J.) would have offered a suitable precedent.

so La Forest, Sopinka, Gonthier, Cory, and Major JJ. concurring.

61 Air Canada, supra note 5 at 606, citing Megarry V.C. in Re Montagu's Settlement Trusts, [1987] Ch. 264 at 285. 
knowing assistance. ${ }^{62}$ Knowing receipt was rejected as being inapplicable on the facts. Accordingly, lacobucci J. considered only the principles relating to knowing assistance. He started with Lord Selborne's statement of the principle in Barnes v. Addy that a defendant must "assist with knowledge in a dishonest and fraudulent design on the part of the trustees."

\section{Dishonest AND FRAUDULENT DESIGN}

Iacobucci J. discussed English authorities ${ }^{64}$ and noted the English meaning of dishonest and fraudulent as "the taking of a risk to the prejudice of another's rights which risk is known to be one there is no right to take." ${ }^{15} \mathrm{He}$ then had to address the divergent Canadian case law on the requirement for a "dishonest and fraudulent design." Where the defendant was a director of the corporate trustee, there was a question as to whether such a "dishonest and fraudulent design" was required.

The English test had been adopted in one line of authority ${ }^{66}$ In the second line of authority defendant company directors were held liable even though the breach of trust was innocent or negligent. ${ }^{67}$ lacobucci $\mathrm{J}$. indicated his understanding that the second line of authority was a contextual development by stating that:

[t]he modified standard found in many of the Canadian cases involving directors of a closely held corporation reflects a difficulty with the application of the strict Barnes $\mathbf{v}$. Addy standard to cases in which the corporate trustee is actually controlled by the stranger to the trust. ${ }^{\text {ss }}$

Iacobucci J. then adopted an approach to this issue that puts the law in Canada firmly on a different footing than the law in other jurisdictions. Iacobucci J. clearly rejected an argument that liability should depend on the dishonesty of the assister. He stated:

The term "knowing participation" is used and then put aside in favour of the specific tests from Barnes v. Addy.

Barnes v. Addy, supra note 2 at 252, Lord Selborne L.C., cited by lacobucci J. in Air Canada, supra note 5 at 608 .

Carl Zeiss Stiffung v. Herbert Smith \& Co. (No. 2), [1969] 2 Ch. 276 [hereinafter Carl Zeiss Stiftung]; Belmont Finance Corp. v. William Furniture Ltd. (No. I), [1981] 1 All. E.R. 118 [hereinafter Belmont Finance]; Selangor, supra note 22. Baden, supra note 14 at 406.

Scott v. Riehl (1958), 15 D.L.R. (2d) 67 (B.C. S.C. (T.D.)) [hereinafter Scott]; Wawanesa Mutual Insurance Co. v. J.A. (Fred) Chalmers \& Co. (1969), 7 D.L.R. (3d) 283 (Sask. Q.B.). It was also adopted in MacDonald v. Hauer, supra note 57. This case did not deal with a company director. MacDonald v. Hauer was cited in Quiamco v. Acosta (1987), 30 E.T.R. 127 (B.C. S.C. (T.D.)). Cashman L.J.S.C. cited and applied Buck v. Dickinson (1977), D.L.R. (3d) 759 (B.C. S.C. (T.D.)) as authority for the traditional "knowing assistance" formulation. However, the ultimate order permitting tracing indicates a proprietary claim.

lacobucci J. referred to Horsman Bros. Holdings v. Panton, [1976] 3 W.W.R. 745 (B.C. S.C. (T.D.)); Trilec Installations Lid. v. Bastion Construction Led. (1982), 135 D.L.R. (3d) 766 (B.C. C.A); Henry Electric Ltd. v. Farwell (1986), 29 D.L.R. (4th) 481 (B.C. C.A.) [hereinafter Henry Electric]; Andrea Schmidt, supra note 48; Austin v. Habilat Development Lid. (1992), 94 D.L.R. (4th) 359 (N.S. S.C. (A.D.)). See also Gough Electric Lid. v. G.S. Electric Ltd., [1987] B.C.J. No. 1979 (Co. Ct.) online: QL (BCJR), where Henry Electric was applied. 
[T] he issue here is whether the breach of trust was fraudulent and dishonest, not whether the appellant's actions should be so characterized.... It is unnecessary, therefore, to find that the appellant himself acted in bad faith or dishonestly. ${ }^{69}$

The approach taken by the Supreme Court of Canada in Air Canada can be contrasted with the approach of the English Privy Council two years later in Royal Brunei. ${ }^{70}$ The Supreme Court of Canada has provided a conservative and literal interpretation of the Barnes v. Addy knowing assistance limb. On the other hand, the Privy Council adopted dishonesty of the accessory as the basis of liability and rejected the concept that the accessory must act with "knowledge."

\section{KNOWLEDGE}

Iacobucci J. then addressed the issue of knowledge. He stated that actual knowledge was needed, although "recklessness or wilful blindness will suffice."71 As authority for the proposition he cited only English cases; namely, Belmont Finance, ${ }^{72}$ Re Montagu's Settlement Trusts, ${ }^{73}$ and Carl Zeiss Stiftung. ${ }^{74}$ The rationale for rejecting any broader heads of knowledge was drawn from Re Montagu's Settlement Trusts, where it was said that constructive notice did not indicate a want of probity and would not suffice for imposing liability. This case adopted a "conscience-based" approach to liability.

Re Montagu's Settlement is a "receipt" case. It is surprising that Iacobucci J. relied on a knowing receipt case to support his argument for "knowing assistance." This is consistent, however, with his opening statement that all forms of third party liability depend on whether the conscience of the defendant was sufficiently affected to justify liability. ${ }^{75}$

This aspect of the decision is significant as lacobucci $J$. adopted a single test for knowledge in all assistance cases. The clear message from the Supreme Court is that a unitary test, which ignores the liability of the defendant, is appropriate. However, this is justified solely by a mechanical application of English authorities. There is no clear policy-based rationale for the adoption of the test.

\section{CRITICISMS OF THE DECISION}

It is unfortunate that the judgment contains little discussion as to whether the modified Canadian standard was applicable to directors of corporate trustees. Iacobucci J. adopted

Ibid. at 618.

Supra note 1.

Supra note 5 at 608 . Two subsequent cases have noted that Iacobucci J. stated this knowledge test for the defendant's knowledge of the trust, as well as of the breach of trust: Besta International Corp. v. Watercraft Offshore Canada Lid. (1994), 19 B.L.R. (2d) 257 (B.C. S.C. (T.D.)); Gordon v. Winnipeg Canoe Club (1997), 41 C.C.L.I. (2d) 204 (Man. Q.B.).

Supra note 64.

Supra note 61.

Supra note 64.

Air Canada, supra note 5 at 606. 
a generic requirement for both the "dishonest and fraudulent design" and for "knowledge," without further discussion of the particular context in which directors act. Clearly, Iacobucci J. was attempting to ensure that agents of a fiduciary, as a generic class, are not subjected to unduly stringent standards of equitable liability. ${ }^{76}$

However, given the existence of the second line of authority on director liability, further consideration of the issue was warranted. Are company directors who control a small corporation in the same position as, for example, solicitors or accountants to a trust? ${ }^{77}$ The divergence in the earlier case law illustrated that some judges in those earlier cases had taken the view that the identity of these defendants, and the role played by them in transactions, should affect the criteria of liability.

The cases that adopted the view that a director could be liable for an innocent or negligent breach of trust imposed a high burden on company directors. There are valid arguments for why such a level of liability may be appropriate, at least where small companies act as fiduciaries. Company directors are in a position where they should know about the company's legal obligations as trustee. Their close involvement in the company's affairs makes it a relatively simple matter to determine if the company is acting in the interests of the company's beneficiaries. Further, if a director is the sole director of the company or one of only a few directors, each director has significant power to prevent the company from taking action in breach of fiduciary duty. Thus a company director has the means of knowing when wrongful conduct has occurred (without having to make expensive or time-consuming inquiries) and has power to prevent that breach from occurring. Given this, an onerous liability standard will usually correctly impose risk on the company director.

This is in stark contrast to, for example, professional advisers of fiduciaries. For these defendants, it will frequently be much more difficult for them to identify that fiduciary fraud is occurring. Additionally, their available responses when faced with fraud are limited.

If the transaction proposed by the fiduciary client is clearly fraudulent, the adviser can advise the fiduciary against proceeding. If the client wishes to persist in the transaction despite the adviser's counsel, the adviser can refuse to participate in the transaction. This does not prevent the fraud in an absolute sense. The client could choose to engage another adviser with fewer scruples. But the adviser's refusal should have some impact. If the fiduciary needs to spend money to find a more compliant adviser, beginning the transaction again, this will significantly increase the fiduciary's transaction costs. Thus the fraud becomes less profitable. Further, the fiduciary may be discouraged from persisting with the fraud if it appears difficult to find an adviser who will participate.

He quoted from R. Sullivan, "Strangers to the Trust" [1986] Est. \& Tr. Q. 217 at 246. Sullivan's argument is that the invidious position of an agent who is contractually required to follow the principal's instructions should give the agent some protection from liability if the agent is merely following orders.

McLachlin J. (as she then was) preferred to address this issue in a case where the issue was directly on point "[g]iven the importance and difficulty of the question." Supra note 5 at 595. 
In other cases the adviser will not be able to easily identify that the proposed transaction is fraudulent. This is due to the role played by advisers in their transactions with fiduciaries. Advisers are often involved in complex transactions. The client is likely to want to deceive the adviser as well as the beneficiary. The adviser will be further hampered if the client is engaged in "multiple contracting"78 and the adviser is only briefed in relation to part of the transaction. ${ }^{79}$ Even if the transaction is being done within the same firm, knowledge may be split between various individuals, making it difficult for any individual to obtain a complete picture of the transaction. ${ }^{80}$

It must also be remembered that an adviser may have limited options when faced with potential client fraud. In most instances, the action available to the adviser is to refuse to act further for that client. However, in some circumstances, the adviser may have no useful options. The adviser's dilemma was noted in the Australian case of Adams v. Bank of New South Wales. ${ }^{81}$ In that case a solicitor held money on behalf of the client in the solicitor's trust account. The solicitor knew that the client owed fiduciary obligations in relation to the money. Moffitt $P$. addressed the dilemma faced by the adviser. He stated:

If the client directs the solicitor to pay the money to another solicitor or to the trustee personally or to some other person, the solicitor is obliged to follow his client's directions. If the solicitor suspects that upon the money being paid to the client, he will apply some or all of it for purposes inconsistent with the client's duty as trustee or, in the case of a mixed fund to part of which the client is entitled, that he will not divide the fund properly or will not conduct a proper account, no ground arises for the solicitor to refuse to perform his obligation as a solicitor and pay the money as directed by his client. He might refuse to act further for his client, but he could not refuse to pay the money as directed by his client. If he were to refuse, what should he do? Should he conduct some inquiry concerning his suspicions, or commence some proceedings or go behind his client's back to the supposed beneficiaries? What is he to do with the money in the meantime? What defence would he have if he withheld the money and were sued by his client? ${ }^{32}$

Thus it can be seen that the position of company directors and professional advisers, as strangers to the fiduciary relationship, is significantly different.

\section{CONCLUSION TO PART III}

The above discussion demonstrates that the law prior to Air Canada pointed to a potential need for special rules governing the liability of company directors. The Air Canada case presented the Supreme Court with an opportunity to explore the issues

That is, engaging multiple advisers.

See, for example, the New Zealand case of Equiticorp Industries Group Ltd. v. Hawkins, [1991] 3 N.Z.L.R. 700 (H.C.).

Also note that research into social cognition suggests that lawyers are subject to "blind spots" in relation to observing fraudulent conduct by their clients. Once the lawyer has committed to the client's cause, negative facts are downplayed or ignored. See D.C. Langevoort, "Where Were the Lawyers? A Behavioral Inquiry Into Lawyers' Responsibility for Clients' Fraud" (1993) 46 Vand. L. Rev. 75.

[1984] 1 N.S.W.L.R. 285.

lbid. at $290-91$. 
relating to liability for assistance. There was scope and precedent for the adoption of context-dependentrules. A simple comparison of the roles played by directors of corporate trustees and professional advisers to fiduciaries demonstrates that not all defendants are alike. It follows that there is real need for consideration of appropriate liability rules that reflect the differing ability of types of defendants to identify and prevent fiduciary fraud.

However, Iacobucci J. rejected the need for company directors, as a category of defendant, to be governed by a special liability standard. He then went further, reverting to the traditional Barnes v. Addy formulation. This is a generic test which treats all defendants alike. Unfortunately, no real justification was given for the adoption of such a generic test. To say that liability is based in conscience is not a sufficient response. What must be explained is why a single liability rule is appropriate to govern all types of defendants.

\section{MUST THE ASSISTER RECEIVE A BENEFIT?}

One matter was left unresolved by the Supreme Court. This concerns a possible requirement for the assister to have derived a benefit. The facts of Air Canada demonstrated such a derivation of benefit. Valliant received a benefit, as his liability under a personal guarantee was reduced to the extent that the bank appropriated funds from the operating account. However, Valliant did not receive trust funds and could not be made liable as a knowing recipient.

In the Canadian knowing assistance cases prior to Air Canada, directors found liable for knowing assistance had frequently received a benefit as a result of their assistance. Some of these cases could now be dealt with under the knowing receipt head of liability. ${ }^{83}$ However, not every derivation of a benefit from a transaction results in the receipt of trust property. For example, in Henry Electric ${ }^{84}$ the defendant director derived the same benefit as Valliant. When the bank appropriated trust funds, his personal liability to the bank under a guarantee was reduced. ${ }^{85}$

In that case the majority judges considered the director's derivation of a benefit as relevant to his liability, stating:

It is also not to be overlooked that, in addition to foreseeability by Farwell of the breach of trust which occurred, Farwell personally benefited from the breach by reduction of his personal liability on his guarantee to the bank. ${ }^{26}$

In Air Canada, lacobucci J. stated that the stranger's receipt of a benefit may "ground an inference" of knowledge, but "receipt of a benefit will be neither a sufficient nor a

See, for example, Scott, supra note 66 . In this case the defendant director was paid a salary from trust funds.

Supra note 67.

See also Andrea Schmidt, supra note 48. The defendant director was liable, as was the financier. Henry Electric, supra note 67 at 84. 
necessary condition for the drawing of such an inference." ${ }^{\text {87 }}$ Even though Iacobucci J. rejected a nexus between knowledge and the derivation of benefit, he nevertheless regarded the receipt of a benefit as relevant. After finding that Valliant had sufficient knowledge of the breach of trust, Iacobucci J. added:

Furthermore, the appellant received a benefit from the breach of trust, in that his personal liability to the Bank on the operating line of credit was extinguished. Therefore, he knowingly and directly participated in the breach of trust.

The approach of lacobucci J., therefore, merely perpetuates the theory that derivation of benefit is of some relevance to determining liability of a knowing assister. However, no clear principle was formulated.

Justice McLachlin (as she then was) concurred in the result, but reserved her decision on several issues, although she was satisfied that liability should be imposed. The matter of derivation of benefit was of one the issues she reserved for the future. She remarked, "My colleague, I hasten to add, does not himself venture on this question."

Thus the Air Canada case leaves unresolved the question of whether a defendant can knowingly assist in a breach of trust if no benefit is received. The correct answer to that issue is, surely, that no benefit should be required. If the liability is truly one for assistance, it should depend on mental state, ${ }^{90}$ without requiring the plaintiff to prove the defendant to have benefited. The only role that could properly be played by a derivation of benefit is to provide an inference of knowledge (as suggested by lacobucci J.).

If an alternative view of assistance liability was adopted, and a benefit was required, there would be major ramifications on the ability of plaintiffs to sue banks for knowing assistance. A bank that only acted as agent, not receiving trust funds, would rarely be liable as an assister. It would only be liable in transactions where a collateral benefit was obtained by the bank so that assistance liability could be ascribed to it. In the ordinary case where the bank's only benefit is the payment of standard transaction fees, no liability would arise.

Professor Ellinger has argued that a bank assisting in a dishonest and fraudulent design can be expected "to derive some benefit. Otherwise why should it take a stand or meddle in such affairs?"'1 This proposition does not withstand analysis. A bank may have assisted in a breach of trust by paying money out to a fraudster and may be held by the

Supra note 5 at 609.

Ibid. at 619.

Ibid. at 595.

Whether knowledge or dishonesty.

"Reflections," supra note 24 at 166-67. Compare the comments of Huband J.A. in Valley Credit Union, supra note 56 at 635 . He identified the case as one of knowing assistance, saying "[t]his is not a case where the court is invited to construct a trust involving an intermeddler who derives a benefit from the a breach of trust. M.S. Sales was never indebted to the credit union, and no moneys ever found their way into the credit union's coffers." 
Court to be wilfully blind due to the knowledge held by several bank employees. However, the teller dealing with the actual transaction may not have that knowledge, and the transaction may not benefit the bank.

The link between participation and benefit is an issue that needs to be addressed by the Supreme Court.

\section{KNOWING RECEIPT}

On October 30, 1997, the Canadian Supreme Court delivered two judgments on knowing receipt. ${ }^{92}$ The Court reaffirmed its commitment to the two-limbed test from Barnes v. Addy. Additionally, it attempted to articulate the theoretical rationale for knowing receipt liability. In Citadel Assurance ${ }^{93}$ the main judgment for the Court was given by La Forest J. In Gold ${ }^{44}$ the statements of principle were articulated by Iacobucci J., who was in the minority. On issues of principle regarding knowing receipt, La Forest and Iacobucci JJ. considered themselves to be in agreement, and each cross referred to the judgment in the other case.

In both cases there was a heavy emphasis on English authority. English cases debating the standard of knowledge for knowing assistance and knowing receipt were closely reviewed. Ultimately, the Canadian Supreme Court adopted English reasoning when considering how the law of third party participatory liability should be constituted. The decisions adopt a single standard of notice for all cases of receipt.

For the purposes of this article, the facts of Gold ${ }^{\text {s }}$ are sufficient to examine the principles formulated by the Court. Gold and Rosenberg were executors and beneficiaries of a deceased's estate. Rosenberg was Gold's uncle. The relevant trust assets constituted properties held by two companies, Primary Developments Ltd. and Existing Enterprises Ltd. ("estate companies"). Rosenberg was involved in running the estate companies, and Gold signed a power of attorney permitting this to continue. Rosenberg also had commercial interests of his own. His company banked with Toronto Dominion Bank which was also the banker for the estate companies, a co-defendant. The same person at the bank oversaw the banking arrangements for all of these companies, was familiar with the terms of the will, and had a copy of Gold's power of attorney.

Rosenberg needed to alter his banking arrangements for his personal company. It was agreed between himself and the bank that one of the estate companies would guarantee Rosenberg's personal indebtedness and a new loan to his company. The guarantee was

Gold, supra note 7; Citadel Assurance, supra note 8. A shorter version of the following discussion of the cases was presented as part of a larger paper at a banking law conference in Melbourne, Australia on 27 October 2000, and will be published in the official proceedings of that conference. One of the papers has already been published. See S.B. Thomas, "Knowing receipt and unjust enrichment: Diverging responses within the British Commonwealth" (2000) 16 Aust. Ban. Fin. L. Bul. 79.

95 This statement of the facts is drawn from the judgment of lacobucci J. 
ultimately given by Primary Developments. The guarantee was supported by: (1) a mortgage of property held by Primary, and (2) the postponement, by Existing Enterprises, of a mortgage it held over property owned by Rosenberg's company in favour of a mortgage held by the bank. Gold, as one of the directors of the estate companies, signed the company resolutions authorizing the transactions, in particular the guarantee. A law firm acting for all parties provided advice that the transaction was proper and prepared the resolutions for signature.

The following principles can be derived from the two cases:

- The defendant will not be liable for knowing receipt unless the defendant has received trust property for the defendant's own use and benefit. There is no cause of action in receipt against an agent holding property for another. ${ }^{96}$

- The nature of liability for knowing receipt and knowing assistance are quite different. Knowing assistance liability derives from the defendant's participation in a fraud. Knowing receipt liability is restitutionary. ${ }^{97}$

- The defendant is liable as a recipient because "the defendant has improperly received property which belongs to the plaintiff." The dispute between the plaintiff and the defendant is about "who has a better claim to the disputed property. 998

- It is inappropriate to use a "want of probity" test for receipt liability. ${ }^{99}$

- Unjust enrichment is the basis of liability. The defendant is not unjustly enriched unless the defendant has failed to inquire in circumstances where there is a legally recognized duty of inquiry. ${ }^{100}$

- The defendant will be liable if any of categories (1) to (5) from Baden are satisfied. ${ }^{101}$

- The burden of proof is on the plaintiff to satisfy the court that the defendant was not a bona fide purchaser for value without notice. ${ }^{102}$

Gold, supra note 7 at 396, lacobucci J; Citadel Assurance, supra note 8 at 422, La Forest J.

Gold, ibid. at 396; Ciladel Assurance, ibid. at 433.

Gold, ibid. at 399. See also La Forest J. who quotes from Millett J. in Agip (Africa) Led. v. Jackson, [1990] Ch. 265 at 292-93: "[t]racing claims and claims of 'knowing receipt' are both concerned with rights of priority in relation to property taken by a legal owner for his own benefit."

Gold, ibid.

Citadel Assurance, supra note 8 at 434.

The Baden categories of knowledge are adopted by the minority in Gold, supra note 7 at 406, Sopinka J. Neither La Forest J. in Citadel nor Iacobucci J. in Gold expressly adopt the Baden scale. It is clear, however, that they adopt a standard of constructive notice: the defendant will be liable if a reasonable person would have been put on inquiry, and no inquiry was made. The majority statements in fact involve a modification of the Baden test, as both lacobucci J. and La Forest J. look for the conduct expected of a "reasonabie" defendant and not an "honest and reasonable" defendant. Gold, supra note 7 at 400 , lacobucci J. 
- Tracing and third party liability are distinct, but they share a common concept of bona fide purchase for value without notice. ${ }^{103}$

The reasoning in relation to some of these points is examined in detail below.

\section{A. Property IsSues}

The approach of the Supreme Court to matters of property and restitution contains inherent contradictions. The Court stated that the liability of the defendant is restitutionary because the defendant is unjustly enriched if not required to make restitution. In contrast, the Court has also stated that the dispute between the defendant and the plaintiff is a matter of property priorities. These propositions are incompatible.

It appears that the judges lost sight of some essential distinctions between property and restitution. Property claims are made to enforce the plaintiff's continuing proprietary rights in the misappropriated asset. Restitutionary claims are made to recover the value of the misappropriated asset and do not depend on the continued existence of proprietary rights. The Supreme Court blurred these distinctions.

Both La Forest J. in Citadel and Iacobucci J. in Gold adopted the statement from Millett J. in Agip (Africa) Ltd. v. Jackson ${ }^{104}$ that liability for receipt is essentially a question of property priorities. This was contrasted with liability for knowing assistance, which is fault-based. In Gold Iacobucci J. said that the plaintiff's claim could be expressed as follows: "You unjustly have my property. Give it back."10s

This reasoning describes the knowing receipt action as purely proprietary. It suggests that there is no distinction between the knowing receipt action and a proprietary claim consequent upon the use of the tracing mechanism. If the knowing receipt action is for the recovery of property, there is no role for restitution. Further, if the knowing receipt action is purely proprietary, why does it depend on knowledge, whereas a claim founded on tracing does not?

The answer is that the Court misdescribed the knowing receipt action. Liability as a constructive trustee for knowing receipt is distinct from liability as a person to whom trust property can be traced. Liability as a knowing recipient continues, even when the trust property no longer exists or cannot be traced. This was explicitly recognized by La Forest J. ${ }^{106}$ As a result, despite the Court's adoption of Millet J.'s statement, knowing receipt is not "simply a question of who has a better claim to the disputed property." 107

If the property basis of knowing receipt is rejected, the restitutionary alternative will be operative. The crucial distinction is the difference between liability to restore value to 
the plaintiff, and liability to restore property in specie. The liability of a knowing recipient is not to restore property, but to restore value. That is why the liability continues even after the defendant no longer holds the property or its traceable substitute. This is a restitutionary obligation. ${ }^{108}$

Accordingly, it is not correct to say that the plaintiff's claim is: "You unjustly have my property. Give it back." 109 A more accurate claim, which reflects the distinction between property and restitution, would be: "You unjustly had my property and still have its value. Give it back."

This provides the necessary conceptual separation between the consequences of the strict tracing exercise and a restitutionary claim. It is this difference that provides the rationale for a different formulation of liability. The constructive trustee will not be subject to liability in the absence of some form of knowledge being proved. This is because liability does not depend on whether the defendant still holds the property. However, if the property is still in the hands of the defendant, it is for the defendant to satisfy the court why the property should not be returned to its equitable owner. The distinction is between a claim for the return of property and a claim for value received.

\section{B. UNJUST ENRICHMENT}

The view that the recipient's liability is based on unjust enrichment coincides with recent judicial thinking in England, New Zealand, and most recently in Australia. ${ }^{110}$ The view that unjust enrichment is the basis of liability also accords with the arguments made by many English restitution academics. However, the Supreme Court of Canada has taken the step of identifying what it means by "unjust enrichment" in this context. According to the Court, the defendant will not be liable as a recipient unless the plaintiff can prove knowledge of one of the five categories from Baden.

The approach taken by the Supreme Court is contrary to orthodox English restitution theory. Orthodox restitution scholars, most notably Professor Birks, argue that liability should be strict, subject to defences. ${ }^{. \prime \prime}$ The theory of restitution that was developed and explained in England by Goff and Jones ${ }^{112}$ and then by Peter Birks ${ }^{133}$ is based on unjust enrichment. Liability in restitution is determined by asking the following questions: ${ }^{114}$

1. Has the defendant been enriched?

My adoption of the terminology used by the Supreme Court should not be taken as suggesting that I agree with the Court's categorization of knowing receipt liability as restitutionary. But this is not the place to open that debate. Gold, supra note 7 at 399. (H.C.), Smellie J.; Koorootang Nominees Pty. Ltd. v. A.N.Z Bank, [1998] 3 V.R. 16 (S.C.). Not all restitution scholars accept Birks' formulation. See, for example, N.J. McBride \& P. McGrath, "The Nature of Restitution" [1995] O.J.L.S. 33.

112 R. Goff, The Law of Restitution, 4th ed. by G. Jones (London: Sweet \& Maxwell, 1993).

113 P. Birks, An Introduction to the Law of Restitution, rev. ed. (Oxford: Clarendon Press, 1989).

$114 \quad$ A. Burrows, The Law of Restitution (London: Butterworths, 1993) at 7. 
2. Is the enrichment at the expense of the plaintiff?

3. Is the enrichment unjust?

4. Are there defences?

None of the first three elements require consideration of the defendant's mental state. If the first three questions are answered in the affirmative, the defendant is liable in restitution unless a defence is available at the fourth stage of inquiry. Like the common law action for money had and received, the liability is strict regardless of whether the defendant knows the receipt is unjust. The defendant's lack of knowledge may become relevant to a defence. ${ }^{115}$

The English formulation of unjust enrichment liability is very similar to the tests established by the Supreme Court in Pettkus v. Becker. ${ }^{116}$ In that case the Court listed the factors for unjust enrichment as: (1) an enrichment to the defendant; (2) a corresponding deprivation suffered by the plaintiff; and (3) absence of any juristic reason for the enrichment.

\section{THE APPLiCATION OF RESTITUTION THEORY TO RECEIPT LIABILITY}

Birks argues that the four questions used to determine liability in restitution apply to the equitable receipt action. The first two propositions are easily satisfied. It is the third proposition that is difficult in relation to the equitable action. In order to establish that enrichment is unjust, Birks argues that the unjust factor is "ignorance": the beneficial owner of the trust property was unaware of the transfer of the property and did not consent to it. Therefore, the defendant will be unjustly enriched at the expense of the plaintiff unless the defendant is required to make restitution. ${ }^{17}$ The defendant's liability to make restitution arises on receipt of the property, and the plaintiff is not required to prove knowledge on the defendant's part.

\section{THE MODEL ADOPTED IN THE SUPREME COURT}

Birks' view of "unjust enrichment" in its application to equitable receipt liability was rejected by the Supreme Court. In particular, the Court rejected Birks' argument that "ignorance" can operate as the necessary unjust factor which will then render the defendant strictly liable. ${ }^{118}$

IIS For example, bona fide purchase in good faith without notice or change of position.

116 (1980), 117 D.L.R. (3d) 257 at 273-74.

$117 \quad$ P. Birks, Restitution - The Future (Sydney: Federation Press, 1992) at 27-28.

is In England, Lionel Smith has recently put forward some highly persuasive arguments as to why the "ignorance" analysis does not work. He has also suggested that the liability for knowing receipt is not restitutionary. See L. Smith "Unjust Enrichment, Property, and the Structure of Trusts" (2000) 116 L.Q. Rev. 412. 


\section{In Citadel Assurance, La Forest J. stated:}

In my view, the test formulated by Professor Birks, while not entirely incompatible with my own, may establish an unjust deprivation, but not an unjust enrichment. It is recalled that a plaintiff is entitled to a restitutionary remedy not because he or she has been unjustly deprived but, rather, because the defendant has been unjustly enriched.... To show that the defendant's enrichment is unjustified, one must necessarily focus on the defendant's state of mind not the plaintiff's knowledge, or lack thereof."19

The rejection of strict liability for receipt is, perhaps, no surprise. In discussing the attitude of Canadian courts to unjust enrichment, Fridman has suggested:

the main thrust of Canadian decisions is towards... determination of liability, not on the basis of the notion of benefit (although it may have some relevance sometimes), but by reference to the nature of the defendant's conduct vis-d-vis the plaintiff. ${ }^{120}$

This permits a much more flexible approach to the question of unjust enrichment than that offered by English restitution scholars. The Supreme Court's approach in these cases is an example of that flexibility.

However, the Supreme Court does not adequately justify its adoption of a test based on notice. In choosing notice over knowledge the Court relied on English authorities, which support a distinction between the test for "assistance" and the test for "receipt." But no attempt is made in England, or by the Court, to explain why a unitary standard is appropriate in all cases of receipt. ${ }^{121}$ Thus a single liability test is established without discussion of the contexts in which such unjust enrichment can occur and the ways in which various defendants can protect against the risk of fiduciary fraud.

Consider the following two simple examples:

- A restaurant accepts cash from a company director in exchange for a meal;

- A casino accepts a cheque from a trustee drawn on a trust account in exchange for gaming chips;

Clearly, in such different scenarios, the defendants do not all have the same ability to identify the fiduciary fraud and act to prevent it. Accordingly, it seems difficult to justify a liability test that imposes the same standard on all of them. The casino which accepts a cheque drawn on a trust account is presented with a transaction that is prima facie

Supra note 8 at 435 . For an orthodox restitutionary critique of this analysis, see M. Bryan, "The Receipt-Based Constructive Trust: A Case Study of Personal and Proprietary Restitution in the Supreme Court" (1999) 37 Alta. L. Rev. 73. Canadian Principle of Unjust Enrichment: Comparative Insights into the Law of Restitution" (1999) 37 Alta. L. Rev. 1. The author criticizes Canadian courts for their application of restitutionary analysis on the basis that courts have been "more concerned with results than with principle" at 16. Although some differentiation of circumstances can be achieved by defences, the question is where the primary burden of proof should lie. 
wrongful. It can prevent the fraud by the simple expedient of refusing to accept the cheque. A liability test that only requires this defendant to make reasonable inquiries may not give sufficient incentive to this defendant to prevent fraud. A strict liability test may be more appropriate.

In comparison, the restaurant that accepts cash will have no reason to suspect fraud in the absence of other suspicious circumstances. It has no reason to suspect that the customer is a fiduciary. On what basis would it make inquiries? Further, such inquiries would be time consuming, expensive, and unlikely to identify the existence of fraud. In such a transaction, a "reasonable person" standard may demand too much of this defendant.

Recent developments in England will be interesting in this regard. The English Court of Appeal has recently rejected the knowledge-based tests, instead proposing that the liability test for this claim should depend on whether the receipt was "unconscientious." 122

\section{C. “NOTICE" AND "DUTY TO INQUIRE"}

Further criticisms of the decisions can be made. As stated above, the Supreme Court has adopted a notice-based test for knowing receipt liability. The plaintiff must satisfy a court that the defendant is not a bona fide purchaser for value without notice. The defendant will have notice if any of the five knowledge/notice categories from Baden are satisfied.

How does this test relate to the "put on inquiry" test developed for knowing participation? In Citadel Assurance La Forest J. cited a number of authorities that applied the "put on inquiry" test in support of the argument that only constructive knowledge is required for receipt liability. Among the decisions he referred to are Groves-Raffin, ${ }^{123}$ Carl B. Potter, ${ }^{124}$ Arthur Andersen, ${ }^{125}$ and Re Glenko. ${ }^{126}$ Iacobucci J. also cited Carl $B$. Potter, treating it as a knowing receipt case.

This can be seen as an attempt to bring the earlier authorities into line with the Court's new rhetoric. The message is clear: the "put on inquiry" test is merely a manifestation of the notice test for knowing receipt. The "put on inquiry" test is thus offered as a test of general application, rather than one of particular application to banks. This is consistent with the Supreme Court's attempt to formulate third party liability rules that are context neutral. ${ }^{127}$

Bank of Credit and Commerce International (Overseas) Ltd. v. Akindele, [2000] E.W.J. No. 3247 (C.A.), online: QL (EWJ).

Supra note 18.

Supra note 20.

Supra note 31 .

Supra note 38.

Although both of these cases were against banks as defendants, the Court was clearly stating rules of general application. 
But in adopting Carl B. Potter the Supreme Court committed a sleight of hand, without admitting it was doing so. In Carl B. Potter the Court had stated a very loose test of "put on inquiry." It was stated that the relevant test was whether the defendant was put on inquiry that the funds being dealt with were trust funds. ${ }^{128}$ In Citadel Assurance it is clear that despite the adoption of Carl B. Potter as a knowing receipt case, the legal test is significantly tighter. There is, however, no acknowledgment that any alteration has been effected.

Gold and Citadel Assurance were both cases where the defendant had actual knowledge of the existence of the trust. This was not sufficient to render the defendants liable as a constructive trustees. In Citadel Assurance La Forest J. made the point strongly, stating: "Indeed, without constructive or actual knowledge of the breach of trust, the recipient may very well have a lawful claim to the trust property." 129

In the context of a knowing receipt claim, and given the unjust enrichment rhetoric in the Court, the approach taken by La Forest $J$. is surely correct. The mere fact that the property is trust property does not prevent the transfer to the defendant being proper. It is only if a breach of duty has been committed that the defendant will be required to make restitution to the plaintiff.

The problematic aspect of this analysis is the incorporation of the Carl B. Potter type of case under the knowing receipt label. In Citadel Assurance La Forest J. identified the existence of the "knowing dealing" category. However, the Canadian authorities that reflect inconsistent dealing liability were analyzed as cases of knowing receipt. Thus it may be that in the banking context, no distinction will be drawn between the types of transactions in which the bank can obtain trust funds for its own benefit. If this is the case, banks that appropriate funds from an operating account to reduce a customer's liability on overdraft will now be significantly better off. The bank will need notice of the breach and not merely notice of the trust nature of the funds. This is not a good result.

\section{Application of the Notice Test}

The judgments in Gold demonstrate considerable confusion in the application of this test. The majority held that the bank did not have notice of a breach of trust. Sopinka J. stated that it had acted reasonably and was not under a duty to make further inquiries. Iacobucci J., for the minority, would have held the bank liable. The factor that was productive of division and confusion within the Court was the applicability of principles enunciated by the House of Lords in Barclays Bank Plc. v. O'Brien. ${ }^{130}$

Sopinka J., for the majority, stated that the defendant did not need to make inquiries as to possible breaches of trust based on the information it possessed. This conclusion was based partly on the fact that solicitors had attested to the validity of the guarantee, and 
Rosenberg's share of the estate at that time was worth much more than the amount of the guarantee.

Sopinka J. then addressed Iacobucci J.'s argument (discussed below) that the bank should have ensured that Gold received independent legal advice. This argument is based on the principles laid down in $O^{\prime}$ Brien. ${ }^{131}$ In that case the House of Lords laid down a test of constructive notice that would prevent a bank from enforcing a guarantee. In a situation where the surety cohabited with the primary debtor, the bank would be fixed with notice of any wrongdoing committed by the debtor to obtain the surety's consent to act as guarantor.

According to the House of Lords, the bank would be put on notice because of two factors: (1) the transaction was not to the benefit of the guarantor; and (2) there is a higher risk of undue influence or other wrongdoing having been committed by the primary debtor in a cohabitation relationship than in other scenarios. The bank can only enforce the guarantee if it has taken reasonable steps to ensure that the surety entered the transaction freely and with knowledge of the facts. The bank will only be considered to have taken reasonable steps if it advises the surety of the risk he or she is running and advises the surety to obtain independent legal advice. ${ }^{132}$

Sopinka J. distinguished the $O^{\prime} B r i e n$ case from the facts before him. It is unclear from his judgment whether he saw the $O^{\prime}$ Brien issue as an extension of the argument that the bank was put on notice or whether he saw it as a separate claim by a surety. The context of the discussion suggests the former conclusion to be more likely. If this is the case, then the majority has failed to distinguish between notice for a knowing receipt claim and notice for a claim under $O^{\prime}$ Brien. Although the term is the same, the facts of which the bank must have notice are decidedly different. Similar confusion is markedly evident in the judgment of Iacobucci J. for the minority. ${ }^{133}$

Iacobucci J., who dissented, would have held the defendant bank liable on the basis that it had sufficient knowledge of the breach of trust. ${ }^{134}$ In assessing whether the bank had notice of a breach of trust committed by Rosenberg, Iacobucci J. drew directly on $O$ 'Brien. He analogized the relationship between Gold, Rosenberg, and the bank as one within the principles stated by the House of Lords. He relied on the following statement by Lord Browne-Wilkinson:

[I]n a case where the creditor is aware that the surety reposes trust and confidence in the principal debtor in relation to his financial affairs, the creditor is put on inquiry in just the same way as it is in relation to husband and wife. ${ }^{135}$

Ibid.

Ibid. at 199.

Because lacobucci J. clearly did draw a link between $O^{\prime} B r i e n$ and the case under consideration, the analysis of the case will concentrate on his judgment.

Agreeing with him on this issue were La Forest and Cory JJ.

Supra note 130 at 198. 
Thus, Iacobucci J. reasoned that the bank was on notice of Rosenberg's breach of trust.

The analogy between the $O^{\prime}$ Brien situation and the knowing receipt claim under consideration by the Court is wrong. $O^{\prime} B r i e n$ concerns rescission of transactions due to undue influence. If the case is truly within the ambit of $O^{\prime} B r i e n$, there was no need for a knowing receipt finding to be made at all.

Consider how the case could have been argued using $O^{\prime}$ Brien. Gold would have argued that he was misled by his uncle as to the effect of the guarantee and that the bank had notice of this wrongdoing. On this approach, the questions for consideration would have been whether the extension of $O^{\prime} B r i e n$ to non-cohabitation situations applied. In particular, the Court should have closely examined how the $O^{\prime}$ Brien principles should be extended where the surety was not an individual.

On this analysis, the trust relationship would not be relevant to consideration of the legal principles. The only question is whether the personal relationship between Gold and Rosenberg was such that it was likely that Rosenberg acted wrongfully so that there was no true consent by Gold to the transaction. If this was such a relationship and such wrongdoing had occurred, the bank would have needed to advise Gold to get independent advice.

The alternative approach is to regard the case as a knowing receipt case. This is how the Supreme Court identified the relevant claim. It is unclear how $O^{\prime} B r i e n$ becomes relevant in a knowing receipt case. Nothing in the Supreme Court judgments explain this mystery. The relevance of $O^{\prime} B r i e n$ might have been rationalized as follows. If the bank is defending a claim of knowing receipt, the legal issues are: (1) Was a breach of trust committed by the trustee? (2) Did the bank have the relevant knowledge that a breach of trust was committed? (3) Did the bank receive trust property?

The bank knew that there was a trust, and it knew of the terms of the will that established the trust. The breach of trust is the self-dealing by Rosenberg. The bank knew the purpose of all transactions, and it knew that the guarantees were given to support personal borrowings by Rosenberg. Therefore, it would seem the bank had notice of facts that would indicate to an honest and reasonable person that a breach of trust had been committed.

Leaving aside the question of whether the bank received trust property, the bank's position at this stage is precarious. Prima facie, if the transaction involved a breach of trust, the bank is implicated by its involvement. In order to protect itself, the bank would have to make inquiries to satisfy itself that no breach of trust had occurred.

The analysis so far is consistent with the approach taken in the Supreme Court. The next question would then be: What inquiries could an honest and reasonable bank be expected to make to ensure that no breach of trust had occurred? It is at this point of the analysis that the reasoning in the Supreme Court decision breaks down. The judges forgot to ask themselves the crucial question: What exactly constitutes the breach of trust for which the bank must have notice? 
Iacobucci J. held that Rosenberg had committed a breach of trust due to his self-dealing with the property held under the power of attorney. ${ }^{136}$ If there truly was a breach of trust, it is unnecessary to resort to $O^{\prime}$ Brien to determine the issue of knowledge. ${ }^{137}$ The bank's notice, or lack thereof, could have been sufficiently determined from its knowledge of the circumstances surrounding the transaction. The principles of knowing receipt, as interpreted by the Court, impose a duty on the bank to inquire once it has a sufficient level of knowledge. On this analysis $O^{\prime}$ Brien is otiose.

The crucial question overlooked by Iacobucci J. was whether an actionable breach of trust had in fact occurred. There would be no breach of trust if Gold had truly consented to the self-dealing of Rosenberg. In this case there was, at least, apparent consent. Therefore, the bank could have argued that the apparent consent removed any suspicion of wrongdoing.

A further question would then arise. To what extent is the bank required to ensure that the apparent consent of Gold, manifested by his execution of the guarantee, was not real? This is where a claim of undue influence or misrepresentation becomes relevant to the knowing receipt claim against the bank. The Supreme Court could properly have drawn on $O^{\prime} B r i e n$ to ask if the bank was fixed with notice that the consent to the guarantee was not freely given.

This is not how the Supreme Court tackled the issue. Iacobucci J. did not address whether any misrepresentation, undue influence, or other equitable wrongdoing had, in fact, occurred. Sopinka J. actually indicated his agreement with the Appeal Court's conclusion that Gold had properly given his consent to this transaction. Therefore, this must mean that he believed Gold's consent to be valid. If so, why did Sopinka J. then address the question of notice?

If Gold's consent was properly given, two significant consequences follow. First, there is no equitable wrongdoing of which the bank could be fixed with notice. Accordingly, the outward signs of consent can be believed. This would remove any potential grounds of complaint under $O^{\prime} B r i e n$. Second, the consent, when properly given, removes the ability of Gold to claim that his trustee committed a breach of trust. Logically, this must prevent Gold from claiming that the bank received trust property transferred to it in breach of trust.

Gold, supra note 7 at 401.

Iacobucci J. also applied the Canadian decision of Bertolo v. Bank of Montreal (1986), 57 O.R. (2d) 577 (C.A.). In this case a mother mortgaged her house as security for a promissory note given to the bank. The mother was the principal debtor, but the loan was given to finance her son's business project. The mother was not fluent in English and had a low standard of education. When the mother was advised by the lawyer acting for both the bank and her son, the bank accepted that advice as sufficient to protect the mother's interests. It was held that the bank was unable to enforce the mortgage against her. There was no suggestion that the son had engaged in any improper conduct to obtain his mother's consent to the transaction. The requirement for independent advice stemmed from the mother's disadvantage in the transaction vis-ad-vis the bank. La Forest J. rejected the applicability of this case. Even if the facts in Gold were similar, the test is still not relevant to notice of a breach of trust. 


\section{E. Has the Defendant "Received” Trust Property?}

In Gold the Court was split on whether the facts demonstrated a "receipt of trust property" by the bank. A majority of the Court held that the Bank had received trust property. ${ }^{138}$ Iacobucci J. (in the majority on this issue) stated:

The mortgage, as security for the guarantee, conferred on the Bank a proprietary interest in the trust property. The guarantee ... supported by a collateral mortgage over property owned by [the trust], in my view, constitutes property which can be made the subject of a knowing receipt claim. Even if one takes the position that the guarantee does not constitute trust property, the giving of the guarantee confers a valuable benefit on the Bank and correspondingly encumbers the estate and detracts from its value. The benefit conferred on the Bank and the resulting loss in value suffered by the estate are sufficient, in my view, to bring the guarantee within the knowing receipt category of liability. ${ }^{139}$

Three judges, on the other hand, adopted a conservative approach to the meaning of "receipt." Justice Sopinka referred to the Oxford Dictionary definition of receive and stated, "I would say that to receive trust property means, at a minimum, to take the trust property into one's possession." 140 Sopinka J. then rejected the notion that by taking security over the trust property the bank received trust property into its possession.

This conflict within the Court illustrates that the adoption of an unjust enrichment based approach to knowing receipt has resulted in a broadening of the concept of receipt. The view of Sopinka J. represents the traditional view, which is concerned with identifying the passing of title or possession of trust assets. The view of lacobucci J., on the other hand, represents a broader conceptual notion of "receipt," which is consistent with the unjust enrichment approach. Although no property was transferred by the execution of the guarantee, proprietary rights were created in the bank. This resulted in a change in value of the trust property. That change in value represented a deprivation to Gold as beneficiary and an enrichment to the bank.

\section{Conclusion}

This article has demonstrated that considerable confusion exists in Canada in relation to liability for third party participation in a breach of fiduciary duty. The Supreme Court has recently redefined the basis for third party liability. Until recently the liability tests were developing in a context-specific fashion. In particular, tests for the liability of banks as knowing participants and for directors as knowing assisters developed from their specific contexts. The trend suggested that the courts regarded some groups of defendants as more culpable than others. This could be interpreted as unarticulated economic reasoning. Although there were faults with the reasoning, it is suggested that this was preferable to the approach since adopted in the Supreme Court.

On this issue, Gonthier J. joined the dissentients in holding that there was a receipt. However, he felt that the bank had not failed its duty of inquiry. Accordingly, with Sopinka, McLachlin, and Major JJ. he formed a majority on the ultimate determination that the bank was not liable. 
In the decisions of Air Canada, Gold, and Citadel the Supreme Court has attempted to establish rules that will be context independent. The rigid Barnes v. Addy categories of "assistance" and "receipt" have been adopted. Earlier authorities on banks and company directors are incorporated and explained as either knowing assistance or knowing receipt decisions. Insufficient justification is given for this change in approach. In particular, no attention is paid to the question of whether a single standard of liability in each of the liability categories is appropriate. In relation to "knowing assistance" the Supreme Court's strong reliance on English authority and its devotion to Lord Selborne's test do not adequately deal with the issues which cried out for resolution.

These decisions mark an unfortunate turn in the development of a coherent Canadian law of third party liability. 